\title{
Children Fleeing Domestic Violence to Emergency Accommodations: Education Rights and Experiences
}

\author{
Sabreen Selvik ${ }^{1,2} \oplus \cdot$ Cathrine Thjømøe ${ }^{3}$
}

Accepted: 25 May 2021 / Published online: 25 June 2021

(c) The Author(s) 2021

\begin{abstract}
Domestic violence forces many families to flee to emergency accommodations. This article focuses on children's experiences of schooling and life at confidential addresses, and to what extent their legal right to education in the face of domestic violence is safeguarded in practice. Data were collected from interviews with 20 children aged 6-16 with multiple relocations at Norwegian refuges for abused women. Interviews were coded using the constructive approach to grounded theory. Data were analyzed using Antonovsky's theory and interpreted within the context of Norwegian and international law, examining the rights of children to education versus the legal rights of abusers. The findings indicate that children's rights to education and a life without violence may be sacrificed in favor of due process for abusers. The article suggests concrete protective measures to help safeguard these rights, and calls on policymakers and support agencies worldwide to rethink their policies and practice.
\end{abstract}

Keywords Refuge $\cdot$ Confidential Addresses $\cdot$ Children $\cdot$ Domestic Violence $\cdot$ Education $\cdot$ Rights

\section{Introduction}

Domestic violence forces many children, either alone or in the company of their non-abusive parent, to seek protection at emergency accommodations, both in Norway and worldwide. Emergency accommodations can have many forms and locations. Some children and mothers may seek temporary protection at the homes of trusted family or friends and may move to a different community or country (Hogan and O'Reilly, 2007). Others turn to refuges for abused women (Mullender et al., 2002; Øverlien, Jacobsen and Evang, 2009; Chanmugam, 2009). The Child Welfare Services (CWS) may separate children from their abusive parent(s) and place them alone with foster families or at institutions. In extreme cases,

Sabreen Selvik

Sabreens@Oslomet.no

Cathrine Thjømøe

c.thjomoe@gmail.com

1 Faculty of Education, Oslo Metropolitan University, Oslo, Norway

2 Østfold University College, Halden, Norway

3 The Norwegian Civil Affairs Authority, Oslo, Norway the police may also, for safety reasons, relocate children, alone or together with their non-abusive parent, to an emergency accommodation (Odland, 2018). Some children may be displaced multiple times to multiple emergency accommodations and may seek protection repeatedly throughout their childhood. Reasons for multiple displacements can be complex; the available literature suggests they are mostly safety-related (Bracewell, 2017; Chanmugam, 2009; Øverlien et al., 2009). The majority of children may be able to relocate, either alone or with their non-abusive parent, to a permanent home away from the abuser after their stay in emergency accommodations. However, others may need the police to put stricter security measures in place before they can move from their emergency accommodations. For example, they may need to move to secret addresses: what we call in this article confidential addresses. In scenarios where children are fleeing domestic violence, they will inevitably experience absence from school and/or preschool, owing to the high risk of abduction and harm by the abuser (Chanmugam, 2009; Mullender et al., 2002). Limited research exists on the living conditions and school experiences, educational needs, and legal rights to education of children experiencing domestic violence. One reason may be that the high security measures surrounding this group of children 
means they constitute a 'hard-to-reach' research population. The present article focuses on the experiences of children who have undergone multiple relocations among refuges for abused women. It explores their perspectives on their living conditions and opportunities for schooling, and juxtaposes their experiences with an examination of how their right to protection and education is understood in theory and implemented in practice. Using empirical data from children, this article aims to answer the following questions: How do children experience multiple relocations at refuges for abused women as a result of domestic violence? What are their perceptions of school? How are their legal rights to protection and education safeguarded in practice?

\section{The Norwegian Context}

\section{Refuges for Abused Women}

Currently Norway has 45 refuges for abused women that cover the whole country. They are municipally operated, free-of-charge emergency accommodations for victims of intimate partner violence and their children up to age 18, when they are in need of protection. Most of the refuges have hidden addresses and all employ some security measures, such as safe doors with security cameras and roundthe-clock employees, including on weekends (Bufdir, 2014-2019; Øverlien et al., 2009).

\section{Security Measures}

Various types of security measures exist, both low- and high- security measures. Low-security measures are open to victims without the need for a referral from other services. These include the emergency accommodations at refuges for abused women. Norway also has two classes of high-security 'confidential addresses': Code 6 and Code 7. Code 6 addresses are termed 'strictly confidential' and are not visible in the National Population Register, either to public authorities or private individuals. Code 7 addresses are termed 'confidential' and are visible to public authorities, but not private individuals (Folkeregisterloven [The Population Registry Law] $\S$ 10-4, 1972; Beskyttelsesinstruksen [The Protection instruction Act], 1972, §4). Usually, it is the police who decide whether to adopt high-security measures in an individual case. The police also consider the suitability and needs of the person(s) being moved before a placement decision is made (Eidheim, 2007). Placements at Code 6 and Code 7 addresses are one of the most serious security measures available. Other high-security measures include restraining orders; restraining orders combined with electronic monitoring to track the movements of the abuser; a security alarm for the victim; and the imprisonment of the abuser (Beskyttelsesinstruksen [The Protection instruction Act] 1972, §4). In addition, the police employ a risk measurement tool called SARA (Spousal Assault Risk Assessment Guide) in domestic violence cases. It gives the police guidelines for initiating action in domestic violence cases and preventing further violence (Politidirektoratet [Police directorate], 2014; Kropp and Gibas, 2010). However, it focuses on adult violence and does not take into account the presence of children in the household; nonetheless, it can function as an indirect security measure for children (Thjømøe, 2017).

\section{Children at Refuges for Abused Women}

Detailed statistics about children living at women's refuges have been collected since 2003. An annual report is published by the Norwegian Directorate for Children, Youth and Family Affairs. In general, the number of children living at refuges fluctuates between 1,200 and 2,000 children per year. This is demonstrated in Fig. 1, which we developed based on the available refuge statistics. Consistently, more than half of children at refuges have immigrant backgrounds. More than half are 13 or younger. The average refuge stay for a child is about a month; however, children with immigrant background have longer stays. As Fig. 1 shows, statistics on children with multiple refuge relocations are available from 2003 , with an interruption between 2008 and 2013; this interruption notwithstanding, it is evident that children with multiple relocations have made up a stable proportion (11\%-17\%) of all children at refuges over the years, with the exception of 2007 (24\%) and $2015(23 \%)$. Children made multiple stays at the same or different refuges for safety reasons (Bufdir, 2014-2020; Selvik \& Øverlien, 2014).

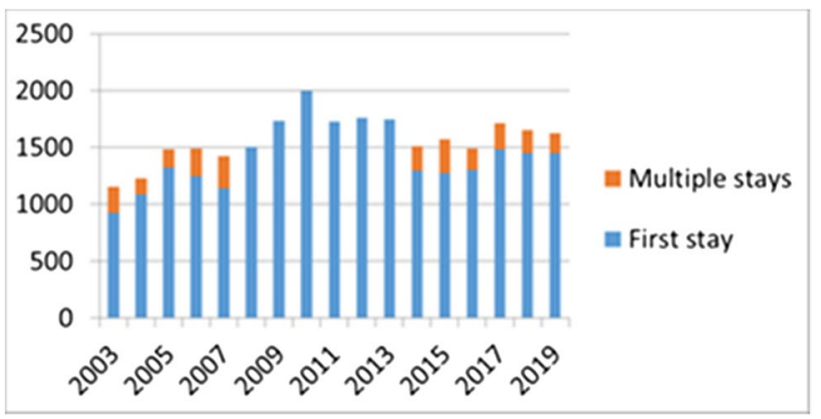

Fig. 1 Percentage of children with multiple refuge relocations, 20032019 


\section{School Attendance}

Figures on schooling for and school attendance by children at refuges for abused women have been collected since 2014, showing an average interruption in schooling of about two weeks. Multiple refuge stays also led to the complete or partial interruption of leisure activities (Bufdir, 2014-2019). The patterns of school attendance for children at refuges since the first year that such numbers were published show that the majority (about 50\%) of school-aged children were able to continue attending the same school. However, for safety reasons, a very few children (less than $10 \%$ ) continued at a different school, while a slight increase from 12\%-17\% experienced a partial interruption of their schooling in 2014-2019. Almost a quarter of the children were completely absent from during 2014-2016; however, a stable reduction from that level is apparent for 2017-2019 to less than $20 \%$ of school-aged children at the refuge (Bufdir, 2014-2020).

\section{Children's Rights to Protection and Education}

Human rights are universal: they apply to everyone. Under the Norwegian Constitution, human rights must be safeguarded and respected (Grunnloven [the Norwegian Constitution], 1814, § 2, § 92). Norway has ratified and incorporated selected international conventions, including the European Convention on Human Rights (ECHR), as Norwegian law, and has given them higher rank than usual law, according to the lex superior principle. The UN Convention on the Rights of the Child (UNCRC) was incorporated into the Norwegian Human Rights Act of 2003 (act of 1 August 2003 nr. 86), although the convention had already been ratified by Norway in 1991 (Menneskerettsloven [The Human Rights Act], 1999). In addition to the ECHR and the UNCRC, separate provisions in the Norwegian Education Act (Opplæringslova) and the Preschool Act (Barnehageloven) further protect the right to education.

The Norwegian Constitution, the Education Act, and international conventions, including the UNCRC, all state that every child has unconditional right and duty to attend school. The best interest of the child shall always be a consideration in all cases and decisions regarding children (UNCRC, article 3). Furthermore, children have the right to life and development (UNCRC, article 6), the right to be heard and the right to non-discrimination (UNCRC, article 12), and the right to a life without violence (UNCRC, article 19) (Convention on the Rights of the Child, 1989, article 3, $6,12,19)$. The Norwegian Constitution $\S 104$ (Grunnloven, $1814, \S 104)$ also provides for the right of children to have their integrity safeguarded. All these rights are interdependent and highly relevant for all children living at confidential addresses.

\section{Previous Research}

A number of studies on children living at refuges for abused women have reported that children describe their moves to refuges as sudden, abrupt, and at times incomprehensible (Mullender et al., 2002; Hogan \& O'Reilly, 2007; Øverlien et al., 2009; Bracewell, 2017; Chanmugam, 2009). In these studies, children also spoke about a number of difficulties related to the moves: staying in touch with friends, feeling sad about leaving their home, possessions, and pets; sudden interruptions to close relationships; and feeling hatred toward the abuser as a result of repeatedly having to change refuges. Children also said that in many cases when making moves, whether planned or abrupt, they were not involved in the planning and decision-making process, or even informed of the decision to move in advance. Many of the children in these studies experienced a number of moves for safety and security reasons. In Øverlien (2012), children living at refuges narrated their perceptions of a 'good' life as a hope for an 'ordinary life', including such elements as going to school, playing and visiting friends, adults with jobs, dinner in secure homes, pets to cuddle. These narratives accord with earlier research on childhood studies that shows that children value social relations in their community and relate it to their sense of belonging (Fattore et al., 2009; Mayall, 2002). The children in Adams' (2011) study also emphasized hobbies and playing with friends and family as important indicators of a 'good' childhood. A Finnish study by Nikupeteri et al. (2015) looked at the experience of children whose mothers were being stalked by their abusers. The children's narratives in this study describe three overlapping forms of security (eroded, lost, and reconstructed) and underline degree of trust and extent of knowledge as two important elements.

Children who experience violence and have to take shelter at emergency accommodations such as women's refuges inevitably experience disruption to their schooling, partly in response to increased risk of abduction or harm by the abuser (Bracewell, 2017; Chanmugam, 2009). The right to education is a fundamental part of safeguarding human dignity, sense of identity, and the opportunity to live as a free human being with the ability to take care of oneself and one's family. According to Pomeroy and Garcia (2011), school is an important stabilizing arena for children during stressful circumstances. It can provide children experiencing violence with a protection and prevention arena (Nordtveit, 2016; Øverlien, 2015). Several studies (Frederick \& Goddard, 2010; Eriksson et al. 2013; Nikupeteri et al., 2015; Overlien, 2015) point out the valuable role teachers can play in recognizing children's experiences of violence and providing them with help they need to rebuild a sense of security. Research has also shown that domestic violence can seriously impede 
the learning process and optimal development. A metaanalysis by Fry et al. (2018) of the relationship between childhood violence and educational outcomes showed that children who experienced any form of violence had a $13 \%$ predicted probability of not graduating from school. But school absence and change of schools can be an additional challenge, potentially causing knowledge gaps, missed instruction, and interrupted social relations (Chanmugam \& Teasley, 2014; Frederick \& Goddard, 2010; Koutselini \& Valanidou, 2014; Stanley, 2011). Selvik and Øverlien (2014) highlighted three fundamental challenges children with multiple refuge relocations face: prolonged and repeated experience of domestic violence, repeated disruptions to relationships, and repeated disruptions to school and preschool attendance. Based on the available literature on domestic violence and children, they concluded that these children are at risk of developing social and psychological difficulties, may have limited access to resources that could help develop their resilience to violence, and may fail or drop out of school.

\section{Salutogenic Theory and Sense of Coherence}

The salutogenic theory argues that our capacity to stay strong and healthy in the face of stressful events greatly depends on the extent to which we have an inner sense of coherence (Antonovsky, 1987, 2012). The core components of this 'sense of coherence' are noteworthy when trying to understand the consequences of living conditions characterized by violence, fear, stress, instability, and unpredictability. Sense of coherence (SOC) refers to an enduring attitude of individuals. It measures how they view life in stressful situations and how they recognize and use so-called general resistance resources (GRR) to preserve and improve their health. GRR can be internal or external; examples include money, intelligence, self-esteem, preventive health orientation, social support and cultural capital, law articles. SOC has three components: comprehensibility, manageability and meaningfulness. These refer, respectively, to the sense that:

(1) the stimuli deriving from one's internal and external environments in the course of living are structured, predictable, and explicable (comprehensibility); (2) the resources are available to one to meet the demands posed by these stimuli (manageability); and (3) these demands are challenges, worthy of investment and engagement (meaningfulness) (Antonovsky, 1987, p. 19).

The theory suggests that individuals with these resources have a better chance of dealing with the challenges of life (Antonovsky, 2012). The findings of a systematic review by
Eriksson and Lindrstöm (2007) on Antonovsky's sense of coherence scale and its relation to quality of life correspond to the core of the Ottawa Charter for Health Promotion- that is, the process of enabling people to live a good life. The Ottawa Charter (1986) suggests that.

health promotion is the process of enabling people to increase control over, and to improve, their health. To reach a state of complete physical, mental and social well-being, an individual or group must be able to identify and to realize aspirations, to satisfy needs, and to change or cope with the environment (p. 17-21).

Eriksson and Lindström's (2007) findings also implicate SOC as a health resource that influences quality of life, and show that SOC plays an important role as an internal resource for controlling life. According to Antonovsky (1987), the impact of social conditions on the health of individuals within a society explicitly points out the responsibility of society to create conditions that foster the strength to cope-that is, SOC.

\section{Methodology}

This article examines school experiences and living conditions of children with multiple relocations at refuges for abused women, as well as their legal rights to education, by drawing on empirical data with children.

\section{Sample and Data Collection}

The empirical data is drawn from the doctoral study, 'A Childhood at Refuges,' that studies Norwegian children with multiple refuge relocations, focusing on their school and refuge experiences, completed in 2018 at the Norwegian Centre for Violence and Traumatic Stress Studies, and the University of Bergen. The study focused on the school and refuge experiences of children who had experienced multiple relocations among Norwegian women's refuges. Eighteen refuges were randomly contacted, twelve were willing to participate in the research, and only five were active recruiters during the fieldwork. Twenty children, with at least one earlier refuge stays, participated in the study, all between the ages of 6 and 16 . They included seven boys and thirteen girls, recruited from five refuges for abused women in different cities in Norway. Sixteen of the children were of Asian background, two were of eastern European background, and two were of Nordic background. The data was gathered using semi-structured interviews while the children were living in safe places away from the abusers. The interviews were recorded and transcribed verbatim. All interviews were conducted by the first author, except for three conducted by the author's $\mathrm{PhD}$ adviser (Carolina $\emptyset$ verlien) during the period that the author was a student (2013-2018). 


\section{Data Analysis and Theoretical Framework}

Data was analyzed inductively and coded using Charmaz's constructivist approach to grounded theory. In this study, the data was allowed to guide the choice of theoretical framework. Data was organized using qualitative data analysis software program (NVIVO 11). A line-by-line approach was used to code the data in short labels/naming segments. Focused codes were used to organize and sort frequent and significant initial codes, which were subsequently used to develop memos. Through memoing, the concepts of 'insecure safety' and 'stressful continuity' emerged from the data. These concepts then guided the choice of Antonovsky's salutogenic theory as a theoretical framework. Data was further understood in the context of national and international articles of law and conventions that safeguard the rights of children to education, including the Norwegian Constitution, the Norwegian Education Act, the United Nations Universal Declaration of Human Rights, and the UNCRC. In addition, the data was viewed through the lens of the security and protection measures available for these children, as well as the rights of abusers to security and due process under the law, according to the Norwegian Constitution, the Norwegian Penal Code, the Norwegian Criminal Procedure Act, universal human rights law, and Case law both national and international.

\section{Ethical Concerns}

The present study was subject to standard ethics oversight by the Norwegian Centre for Research Data (NSD) and followed the research ethics recommendations for the social sciences in Norway. Written consent from the mother was obtained, along with verbal consent from the child. Consent from the abuser was not required, since mothers and children come to refuges in secrecy without the abuser's knowledge. For confidentiality, data were collected from several refuges and any personally identifying information was anonymized or omitted. The nonverbal language of interview participants was evaluated to ensure continuous consent during the interview sessions (Schelbe et al., 2015).

\section{Study Limitations}

Some limitations of the study should be noted. Due to a limited sample size and difficulties in arranging follow-up interviews, the final coding level (theoretical coding) in grounded theory was not achieved. This level of coding can only be reached (Charmaz, 2014) through the process of theoretical sampling, in which further data is gathered from a large sample of information in follow-up interviews. Follow-up interviews were difficult to arrange with the children after they left the refuge.

\section{Findings}

Children living at refuges for abused women experienced changes to patterns of daily life as well as multiple relocations. Some children moved to different refuges, others moved back and forth to the abuser, and a few, with the help of the police, moved to a different city or country or a Code 6 address after their refuge stay. All children experienced a partial or complete absence from school and leisure activities. At the time of the interviews, for the majority of the children interviewed, their moves into and out of refuges had taken place over the course of years, weeks, or months. Some of the children's abusers had received restraining orders; others were involved in ongoing legal proceedings and their children relocated to other refuges for security reasons while waiting to be interviewed by the police or testify in court. The CWS was involved in all of the cases. The abuser was the child's biological father except for one case where the abuser was the stepfather. Across age groups, the children described similar experiences and understandings of their living conditions. In the following section, we introduce the children in this article: Sigrund, age 8, and her brother Josef, age 6 . Made three stays at the same refuge during a one-year period. They were able to continue attending their regular school, after a one-week of absence. Neither were afraid of the abuser showing up at school. Nina, age 11. Made seven refuge stays at five different refuges in different cities over a three-year period. She was completely absent from school during her first three refuge stays. She started at four new schools during the other four stays, spending no more than three months at each. She was afraid of the abuser showing up at school. No restraining order was placed on the abuser. Sara, age 16, and her sister Sina, age 13 . The police followed high-security procedures and moved them with their mother to two refuges at different cities within two weeks. They were completely absent from school. A restraining order was placed on the abuser with regard to their mother. Peter, age 11, and his sister Lucinda, age 11. Made five stays at the same refuge over the span of five years. They were able to continue attending their regular school after a few days of absence. Both were afraid of the abuser showing up at school. No restraining order was placed on the abuser. Camille, age 9. Made four refuge stays at two refuges in different cities. She stayed at the first for one year before moving to the second. She experienced partial absence from school and preschool. With the help of the police, she and her mother were subsequently moved to a Code 6 address. No restraining order was placed on the abuser. Below, we present these children's perceptions of living at refuges and attending school. The data is organized around two main themes: insecure safety and stressful continuity. In these sections we want to let the 
voices of the children receive full attention. Therefore, we intentionally reserve for the Discussion section our analysis involving Antonovsky's (1987) salutogenic theory and our in-depth examination of the children's legal rights. We will, however, consider the perceptions of the children in light of what children have expressed in previous studies on domestic violence, and vis-à-vis the legal rights to education and protective measures currently implemented and available in Norway.

\section{Life at Refuges for Abused Women: Insecure Safety}

In general, children expressed positive feelings about the refuge as a confidential address. When Sigrund (age 8) was asked to talk a little about what it was like to live at her refuge, she said, 'It's a bit like that fun, .... It's very nice ... to play, and go [on trips] with [name of an NGO] .... Play with many other things'. Sigrund rated play and participating in various activities and having fun as the most important things for having a good experience at the refuge. The children we interviewed also expressed other positive aspects of living at the refuge: feeling safe and being able to relax for a while away from the violence; getting support through meeting others in the same situation; relief that their mother finally receiving help from refuge staff; making friends; and feeling seen by other adults. The above experiences of living at the refuge are in line with experiences described by children in previous studies (Bracewell, 2017; Chanmugam, 2009; Øverlien et al., 2009). However, children also described feelings of disappointment and imprisonment while living at the refuge, owing to high security measures, insecurity, instability, and inconsistency stemming from their multiple, abrupt relocations to escape abusers. The emerging concept of 'insecure safety' describes the conditions these children experienced as a result of multiple refuge stays. This concept is based on the following three codes, which all influence one another:

Hiding in Constant Fear When Nina (age 11) was asked why she had moved seven times among five different refuges over a period of three years, she answered:

... Because my dad found us all the time ... and he drove around us for us to be scared ... so we had to hide in a way, so we had to move all the time ... It was a bit tough ... because it was a whole new place and I knew nothing... It's tougher than one would think ... to leave friends ... and leave a place you've been living at for a while ...

Here, Nina describes an upbringing with unpredictable disruptions and continually having to hide for fear of being found by the abuser. Her experience circles around re-establishing her life, making new friendships during each move, only to be uprooted and have to start over again. In addition, Nina's experience points out challenges in several arenas: relationships with others (father and friends), the importance of agency and control, and safety and security (moving all the time). Children in Fattore et al. (2009) considered these elements as significant indicators in their understanding of a 'good' childhood. Nina described a network of resources that included friends, the physical environment (places she related to), and access to information. But living conditions for children who make multiple refuge stays may also disrupt their feelings of safety, security, and stability, as well as feelings of intimacy in key relationships with caregivers, family members, teachers and friends, etc. These relationships are considered by children in previous childhood studies as important to their sense of belonging (Adams, 2011; Mayall, 2002). From a legal point of view, the state has a duty to take action to protect its citizens against abuse from other citizens in society. This was stated by the Norwegian Supreme Court (Rt-2013-588), as well as by the European Court of Human Rights in Strasbourg (application no. 100/1997/884/1096).

Not Being Involved in Planning the Moves This was the case for children of all ages in the interviews, and included both planned and unplanned moves to refuges. When Sigrund (age 8) was asked if she knew she was moving to the refuge for a third time, she answered 'No ... I did not really know ... but when mom said it I knew'. Many of the children, even those, like Sigrund, who had made several refuge stays, did not know that they would be entering the refuge before they were actually on the way. In part, this could have been for security and safety reasons. Nonetheless, such unexpected and repeated disruptions may shake children's sense of stability and cause them to experience insecurity due to constantly wondering whether they will be moving again. Other children in this study reported similar experiences; thus, they can have experienced little control, if any, over their day-today lives. This may make it harder for them to settle down and feel secure, because they experience everyday life as unpredictable and unsafe. Like the children whose narratives are reported in Nikupeteri et al. (2015), the children we interviewed identified extent of knowledge as one of two elements that helped them reconstruct a sense of security. They also reported not being included in the decision-making process when the police became involved and the family situation was assessed using the SARA guidelines. Sara (age 16), for example, seemed afraid after the police moved her and her family to a city she considered unsafe:

... I was in a way daddy's girl [proud smile] I always travelled with him and stuff ... so I kind of knew 
where we had family and friends ... and the only place we didn't have family or friends was [City 4] .... and I said yes to them [the police], but then the first option we got was [City 3] ... I just knew we couldn't [move there] ... But my mom was so scared of [City 1], so we had to move to [City 3] right away ... And here we are, like when we are going out, I am very scared in case one of Dad's brothers sees us, an uncle who could call Dad and say we are here ...

It is not always easy to involve children in advance in the process of moving to a refuge, given the risk involved if the abuser learns about the plans. Yet experiencing unexpected moves with no information provided may evoke feelings of instability, uncertainty, and high levels of stress in children and does little to support them in gaining control of their everyday life and gaining trust in the services around them. This includes trusting that their voices will be heard and that other services are making the right decisions on their behalf. Although Article 12 of the UNCRC states that children have the right to be heard, it is doubtful whether children who are moved to confidential addresses, as in Sara's case, are in fact heard before the decision is made.

The Violence Does not End Experiencing multiple displacements can be demanding, especially when repeated efforts to flee violence do not put an end to the problem. As Nina (age 11) said, '... the goal was to get the apartment and start over again ... When we somehow were moved to more refuges ... it was like one ... it shall always ... continue somehow ... that we will never [end]...'. For the children we studied, violence is not just a one-time experience but a part of their childhood: a repeated cycle of violence followed by escape that they feel 'shall always ... continue somehow ... '. It can be difficult for them to experience their life as stable, controllable, and manageable when the abuser is stalking them from one confidential address to another. Nikupeteri et al. (2015) found that stalking has a psychosocial, emotional, and physical impact on children when their mothers are stalked by a former partner. They describe children's experiences of an atmosphere of fear and feelings of insecurity and point out that professionals across such fields as social and health services, law enforcement, and criminal justice should view the children as victims in cases where mothers are stalked. Nina's experience of being stalked by the abuser corresponds to a prolonged exposure to violence, because of the several displacements involved in fleeing over an extended period of time. According to earlier research on the consequences of domestic violence on children (Koutselini \& Valanidou, 2014; Øverlien, 2010; Stanley, 2011), such experiences can affect children's mental health and well-being. They may also influence whether children feel their efforts to meet the demands and challenges of flight are meaningful, and whether they feel their engagement is worthwhile. From a legal perspective, Nina's experiences constitute a breach in her right to a life without violence (UNCRC, article 19) and her right to the safeguarding of her integrity under the Norwegian Constitution ( $\$ 104)$.

\section{School Experiences: Stressful Continuity}

Children in this study reported that it was good to return to school. However, they differentiated between the act of coming back to and being at school. The fact of physically coming back to school was itself a positive experience. It provided them with continuity in their everyday life. Peter (age 11) said, 'It's good to be there [school]... It was like nothing was changing...' Camille (age 9), like a number of other children, said school activities provided her with an arena where she could forget outside things. She said, 'Since I had so many activities I had just forgotten everything to do with the shelter...'. Others stressed that school gave them a return to normal, everyday activities such as playing with friends and doing schoolwork, which had a positive effect on controlling how much they thought about violence. We can conclude that coming back to school provided children with resources that increased their resilience to their experiences of domestic violence. These findings accord with previous research which indicates that school provides a stabilizing and preventive arena for children experiencing domestic violence (Garcia \& Pomeroy, 2011; Øverlien, 2015; Nordtveit, 2016). The majority of children in this study, however, also spoke about a feeling of overload from being at school after returning from a partial absence. This feeling differed among children and seems to be influenced by three factors. The first was the complexity of their living conditions and the security measures needed for their safety. The second was whether they changed schools or returned to the same school. Third, children pointed to communication with their teacher as a decisive factor in how positive their experience of school was after their return. Children reported finding school challenging and exhausting in multiple ways and described it as offering what we term a 'stressful continuity'. Three codes describe this 'stressful continuity,' which evolves out of feelings of overload evoked by being at school: unsynchronized teaching, indecisive teacher communication, and the making and maintaining of friendships. All of the codes influence one another.

Unsynchronized Teaching Children with multiple relocations among different refuges were subject to restrictive high-security measures that resulted in long periods of absence from school. Nina (age 11) attended four different 
schools for short periods of about three months each. During this time, Nina might start studying a textbook chapter at one school, and leave another school in the middle of another chapter. When she was asked how she experienced the educational transitions between the four schools she attended while she was living in refuges, she described the following experience:

... the teacher [at the new school] did not do anything special because I do not think I said anything, but..., I am somehow, someone who ... has had the highest grades in all subjects ... I tend to learn things pretty quickly ... there was a thing that I did not get well in fifth [grade], it was fractions. ... and at the school I go to now [the fourth new school], ... I told the teacher that I had not learned fractions because it was on the test so then she helped me extra with fractions and then I got extra worksheets ... and then I was able to learn them ...

Nina's school experience can be briefly summed up as 'unsynchronized teaching'. The information taught was, in Nina's case, scattered among the different schools, and some aspects of mathematics (fractions) were missing from her instructions. Children in Nina's situation may experience that newly taught information does not have a foundation to build on. They may therefore develop 'educational blackouts' in their matrix of knowledge, which may in turn, according to a number of studies, result in learning difficulties and possibly school dropout (Fry et al., 2018; Frederick \& Goddard, 2010; Chanmugam \& Teasley, 2014). Children as young as Josef (age 6) who continued to attend their regular school during their refuge stay had a clear notion of where they had difficulties in almost all of their subjects: '... but math is not fun, arts and crafts are not fun,... and food and health, ... and Norwegian and music'. Nina, however, was one of the few children in this study who felt she did well at school regardless of her difficult circumstances. It may have played a role that Nina was fortunate enough to have had a good basic educational foundation from a few stable years of schooling before her cycle of fleeing domestic violence began. Her experience underlines how important it is for teachers to have a handle on the synchrony of education for both older and younger pupils in their classes who have experiences of fleeing violence. Disrupted schooling as the consequence of multiple moves will therefore, by default, constitute a breach in the right to education.

Indecisive Teacher Communication Almost all the children we interviewed said they communicated with their teacher very little or not at all about their domestic situation, their life at the refuge, or their educational and security needs. The majority thought that their teachers did come to know of their situation at some point, but chose not to talk about it with them. When we asked Sigrund (age 8) what it was like to return to school after being absent for two weeks, she offered the following interesting description: '[it was] ... just like when I was sick [smiling] and I came back to school'. No one asked about the reason she was absent: neither the teacher nor her classmates. But it was not easy for Sigrund to start a conversation about it either, as she worried about the consequences: '... If anyone can hear it from the door of the class! ... So I do not like that because they are going to say "do your mom and dad live apart?! and that I do not like ... because ... it's not funny ... '. Talking about their thoughts and worries does not come automatically to children like Sigrund. If teachers do not initiate such conversations, these children's thoughts may never come up at school. Moreover, as in Sigrund's case, children who do not know what the teacher thinks of their situation may develop a perception that the teacher does not want to talk to them, or perhaps that their situation is not serious or important. Such perceptions are in themselves serious, as according to Øverlien (2015), these children need contact with stable, secure, and predictable adults who can offer them support and structure in their chaotic life situation. This is especially important when children feel stressed about the abuser potentially finding and harming them at school, and no restrictions (such as restraining orders) have been placed on the abuser. In addition, a lack of dialogue between teacher and child might give teachers little chance of understanding how best to accommodate the child's needs at school. Children described having difficulty concentrating in class and not always being able to follow the lesson or hand in homework on time. Lucinda (age 11) spoke about her experiences with homework, '[it is] ...not that I do not like to do homework, I do! But..., it is a little difficult to do the homework after all that has happened'. These difficulties stemmed from their thoughts of safety, secrecy, and insecurity, or flashbacks to the violence. Children in this study point to teachers as important resources who can help support them in regaining or recovering feelings of security by accommodating their fears, stability by providing them with a predictable school day, and mastery by giving them schoolwork and activities that they are able to manage. In this way, teachers can help children strengthen their resilience to their experiences of violence and, according to Nikupeteri et al. (2015) and Øverlien (2015), can fulfill their significant role in reconstructing and strengthening children's security and education. Furthermore, the Norwegian Education Act (Opplæringslova [The Norwegian Education Act], 1998, § $1-1,5$ para) states that the purpose of education is for children to develop knowledge and attitudes to master their lives, so that they can participate in work and in the community. Furthermore, it follows from Article 29 of the UNCRC that:

... children's education should help them fully develop their personalities, talents and abilities. It 
should teach them to understand their own rights, and to respect other people's rights, cultures and differences. It should help them to live peacefully and protect the environment .... (Convention on the Rights of the Child, 1989, article 29)

When children are forced to live at confidential addresses, and thus hide their identities, they are less able to 'fully develop their personalities, talents and abilities' (Convention on the Rights of the Child, 1989, article 29).

The Making and Maintaining of Friendships Children who live at refuge may not be always allowed, or may fear, to share their life stories with others. Many of the children in this study sometimes felt the need to tell 'white lies', something that could also help explain why they may have struggled to make new friends or experienced the loss of old friendships. As Sina (age 13) said, '[I] ... haven't told the truth, now almost all my friends will ... end the relationship with me ...'. Experiences like this may lead children like Sina to feel isolated at school. Unable to be themselves with others, they may be prevented from developing new relationships based on feelings of trust and honesty. Children as young as Josef (age 6) were conscious of this situation and had strategies to maintain secrecy around their life at the refuge. When Josef was asked what he said when his school friends asked him where he lived, he said 'I do not say much ... No ... Sometimes when I speak ... When I have said it [where I live] to so many, I just pass them [my friends] by'. Josef's strategy was thus to say as little as possible, but that was not so easy for a young child. When he felt that he might have said more than what he should, his next strategy was to just walk past his friends and ignore their questions. In addition, changing schools may also lead children to feel continually caught between losing old classmates and feeling left out around new ones, who may already have established friendships that do not easily admit newcomers. Sina and Josef are just a few of many children with similar experiences. Such experiences may prevent them from building new relationships that could compensate for old lost ones and provide them with future continuity. Earlier research on children living in refuges shows that children who were able to attend school hesitated to form close friendships there, because they found it difficult to trust others, and feared gossip (Buckley et al., 2007; Hogan \& O'Reilly, 2007; Chanmugam, 2009). However, such relationships are also sources of social support, and important for attaining continuity and strengthening resilience in everyday life. Furthermore, children have the right to development (UNCRC, article 6), which requires interaction with other children or caregivers such as teachers and close family members. If the placement of children at confidential addresses deprives them of such relationships, this may constitute a breach in their right to development.

\section{Discussion}

The life conditions of the children in this study, characterized by a life with many involuntary displacements, being restricted in their freedom of movement and choices, losing friends, and not going to school, all stand in opposition to what children have identified in earlier childhood and refuge research as significant indicators for their understanding of a 'good' childhood (Adams, 2011; Fattore et al., 2009; Mayall, 2002; Øverlien, 2012). Using the core components of Antonovsky's salutogenic theory - 'sense of coherence' (SOC) - to understand the consequences of the living conditions typical for the children of this study, the sections below will reflect upon their experiences through the following three questions. First, how do they make sense of and understand their continuous displacements (the comprehensive element)? The children themselves described these displacements as disappointing, overloading, fearful, isolating, and confusing. Antonovsky's work (1987) suggests that their residential and educational instability, relational discontinuity, and living in hiding because of unsafety bring feelings of unpredictability and inexplicability to both their internal and external environments. Their overall unstructured living conditions, characterized by not knowing when or where their next move will be, may complicate their experience of a sustainable stability which is built on feelings of safety, control, and feelings of place and relational belonging to a safe home and a school environment. Consequently, children may experience difficulties understanding the logic behind their continuous experiences of unattainable safety and thus be unable to experience coherence in their everyday life (incomprehensibility). Second, what resources do they feel are at their disposal to help meet the demands of living at confidential addresses, and what GRRs do they identify (the manageable element)? Children in this study described having mixed feelings towards the resources available to help them meet the demands of living at a refuge, or, later, at a confidential address. They identified five resources: the police, their school, their teacher, their friends, and places they were familiar with. However, when children are continually displaced, elements of these resources may also change (new teachers, schools, refuges, or police contacts), making it difficult for them to recognize and learn how to use these GRRs to preserve and improve their health. Teachers can be important external 
resources who can support children in regaining various internal resistance resources (Antonovsky, 1987). Continual relocation, however, may rob children of the chance to identify teachers as important GRRs who can help them rebuild their sense of security. In other cases, police may move a family to a new refuge or confidential address because the abuser has discovered their whereabouts. In such cases, children may feel that they are not protected by the police and that the abuser is invincible, as they are constantly being moved to places of 'insecure safety'. Thereby, they may gradually lose their feeling of security, which, in line with Antonovsky (1987), is an important internal resistance resource that can aid in experiencing a sense of coherence and in turn help preserve and improve health. Friends are also important external resistance resources (Antonovsky, 2012). Constantly having to tell 'white lies', however, and leaving friends and places where they have been living for some time, also prevents children from building new relationships that might provide them with future relational continuity and social support in their disrupted lives. As seen above, these children's living conditions offer few or no possibilities to regain or develop the necessary GRRs to protect their sense of coherence, which in turn is important for attaining 'a good quality of life', as addressed in the Ottawa Charter (1986). Third, do they perceive the challenge of displacements under threats of violence as worth the investment of energy, or as a burden they would rather avoid (the meaningful element)? The fact of being unable to end their experiences of fleeing the violence seems to bring feelings of confusion and frustration, especially when safety cannot be guaranteed even at the refuge or when protected by the police. The salutogenic theory (Antonovsky, 1987) suggests that prolonged exposure to violence (i.e. because of the multiple displacements involved in fleeing from domestic violence over extended periods of time) can affect whether children feel their efforts to meet the demands and challenges of flight are meaningful, and their engagement is worthwhile. The psychological aspect, and the burden it entails for children to live in hiding and be deprived of continuity, control, and predictability in their everyday lives, may also reinforce their feeling that their battle against their living conditions is not worthy of investment and engagement (is meaningless). We can conclude that the experiences of the children in this study contradict the core components of the salutogenic concept of SOC and are of great concern, because they create schools that provide a stressful continuity instead of a stabilizing arena, and give children an everyday life grounded in insecure safety. There are thus reasons to be concerned about the mental health, wellbeing, and future education of children who are forced repeatedly to flee their homes in response to domestic violence.
Based on how present legislation is designed, it is debatable whether the content of civil rights such as the right to education and a life without violence are safeguarded in the existing protection measures. Confidential addresses are one of several security measures that are implemented when there are weighty reasons for this type of protection. The ways that children at refuges experience school, and how the breaches may occur in their right to education, have transferable value to all children living at confidential addresses, whether they are placed there by their parents, the police, or Child Welfare Services. The problem thus applies to all children and it is therefore important to include all children who live at confidential addresses, regardless of who made the placement or what class of confidential address is involved.

The act of placing children at a refuge or confidential addresses in itself constitutes a recognition of the threatening situation they are subject to. The state has an active duty to protect its citizens against abuse from other citizens in society. In today's legal system, however, due process protections for the abuser are also well established; these include the presumption of innocence and the principle of legality (Grunnloven [The Norwegian Constitution], 1814, § 96) and the right to a fair trial and contradiction (ECHR, article 6; Grunnloven [The Norwegian Constitution], 1814, § 95). As a result, there is a high threshold for implementing security measures that would limit the liberty of an abuser. Generally, there are strict requirements for meeting the burden of proof, and it follows clearly from the Norwegian Criminal Procedure Act (Straffeprosessloven [Norwegian Criminal Procedure Act], 1981, § 170 a) that a coercive measure can only be used when there is a sufficient reason to do so. It is reasonable to believe in some cases that abusers break their restraining orders. For this reason, restraining orders alone are not sufficient protection for people placed at confidential addresses. Despite the fact that the electronic monitoring system was implemented in 2013 (Riksadvokaten [the Director of Public Prosecutions], 2019, p. 1), the arrangement has infrequently been imposed on perpetrators (review of public case law). This reinforces the impression that a perpetrator's right to security takes precedence over a child's right to education and a life without violence. In cases where the electronic monitoring system has been used, it has proven to be a very effective security measure (Riksadvokaten [the Director of Public Prosecutions], 2019). On the other hand, any decision to impose a restraining order with electronic monitoring requires a court order before it can take effect, which in turn may mean a delay in its intended effect: protecting the victim. Meanwhile, the victims, as shown in our case studies, may have to live in hiding. One reason for the minimal use of electronic monitoring may be the lack of immediate means to enforce it. It seems reasonable to believe that the police will prefer to use other security measures that they have the authority to enforce immediately, including traditional 
restraining orders, security alarms, or confidential addresses for victims. In the most serious cases, the police will ask the court for permission to keep the perpetrator in custody while awaiting a hearing. The police are able to enforce these security measures immediately, because they are considered to be preventive measures, not penal measures, which require that the objective and subjective conditions for culpability are met. While security measures that are considered to be penal require a court ruling, preventive measures require only an administrative decision. Norway employs two kinds of restraining orders: a bes $\phi$ ksforbud, considered a preventive measure, and a kontaktforbud considered a penal measure (Ot. Prp. nr. 25., 2008-2009, p. 13). This affects the ability of the police to enforce the measures. By contrast, no such distinction is made in Sweden, where a restraining order in general is considered to be a preventive measure (Ot. Prp. nr. 25., 2008-2009, p. 11).

Furthermore, keeping a child-centered perspective in mind, a restraining order with electronic monitoring can be considered as a relatively mild intervention toward the abuser as compared to placing children in hiding at a confidential address. The 'best interests of the child' and their rights to legal certainty and education should therefore take precedence over the perpetrator's right to privacy. From this perspective, the police should have the authority to impose electronic monitoring on the perpetrator if a restraining order is violated. Another proposal would be to establish express court proceedings that could authorize police to enforce effective security measures immediately, while the abuser awaits a hearing. This would safeguard the abuser's right to legal certainty while protecting children and giving them continuity in their daily life.

\section{Concluding Remarks}

It is important to acknowledge that confidential addresses can be a necessary measure in cases that involve children experiencing violence. However, it is necessary to find alternative security measures that shift the burden from victims to abusers. Doing so would strengthen children's general resistance resources by giving them security and continuity in their everyday lives, network, and environments, whereas the status quo constitutes a rights breach and raises multiple concerns regarding children's mental health, wellbeing, and educational outcomes. It is therefore urgent to highlight and emphasize civil rights, such as the right to education and a life free from violence, when protective measures are chosen. In this way, society becomes salutogenic, not only through its health services, law articles, and regulations, but also in generally functioning to embrace the rights of children under the UNCRC and their right to a good quality of life. Further research is needed worldwide to expand the literature on this group of children.

Acknowledgements Special thanks to Mona-Iren Hauge, Elisabeth Brodtkorb, Else Leona McClimans and Ingrid Barbosa Bjerke for their interest, engaging discussions and fruitful feedback.

Funding Open access funding provided by OsloMet - Oslo Metropolitan University.

Open Access This article is licensed under a Creative Commons Attribution 4.0 International License, which permits use, sharing, adaptation, distribution and reproduction in any medium or format, as long as you give appropriate credit to the original author(s) and the source, provide a link to the Creative Commons licence, and indicate if changes were made. The images or other third party material in this article are included in the article's Creative Commons licence, unless indicated otherwise in a credit line to the material. If material is not included in the article's Creative Commons licence and your intended use is not permitted by statutory regulation or exceeds the permitted use, you will need to obtain permission directly from the copyright holder. To view a copy of this licence, visit http://creativecommons.org/licenses/by/4.0/.

\section{References}

Adams, K. (2011). Unseen worlds: Looking through the lens of childhood. Great Britain: Jessica Kingsley Publishers.

Antonovsky, A. (2012). Helsens mysterium: den salutogene modellen [The mystery of health: the salutogenic model]. Gyldendal akademisk.

Antonovsky, A. (1987). Unraveling the mystery of health: How people manage stress and stay well. Jossey-bass Publishers.

Barnehageloven [The Norwegian Kindergarten Act]. (2005). Lov om barnehager [The Norwegian Kindergarten Act]. (LOV-2005-0617-64). Retrieved January 2020 from https://lovdata.no/dokum ent/NL/lov/2005-06-17-64\#KAPITTEL_1

Barnevernloven [The Norwegian Child Welfare Act]. (1992). Lov om barneverntjenester [child protection services law]. (LOV1992-07-17-100). Retrieved January 2020 from https://lovda ta.no/dokument/NL/lov/1992-07-17-100/KAPITTEL_4\#§4-4

Beskyttelsesinstruksen [The Norwegian Protection Instructions Acts]. (1972). Instruks for behandling av dokumenter som trenger beskyttelse av andre grunner enn nevnt $i$ sikkerhetsloven med forskrifter [Instructions for handling documents that need protection for reasons other than those mentioned in the Security Act with regulations]. (FOR-1972-03-17-3352). Retrieved January 2020 from: https://lovdata.no/dokument/INS/forskrift/ 1972-03-17-3352

Bracewell, K. A. (2017). Teenagers' Experiences of Domestic Violence Refuges (Doctoral dissertation). University of Central Lancashire.

Buckley, H., Holt, S., \& Whelan, S. (2007). Listen to me! Children's experiences of domestic violence. Child Abuse Review: Journal of the British Association for the Study and Prevention of Child Abuse and Neglect, 16(5), 296-310. https://doi.org/10. 1002/car.995

Bufdir. (2014-2019). Krisesenter statistikk [The refuge yearly statistics]. Retrieved in September 2020 from https://bufdir.no/Stati stikk_og_analyse/Vold_og_overgrep_tall_og_statistikk/Krise sentertilbudet_i_norske_kommuner/

Chanmugam, A. G. (2009). Perspectives of young adolescent and mother dyads residing in family violence shelters: a qualitative 
study using life story methods (Doctoral dissertation). The University of Texas and Austin.

Chanmugam, A., \& Teasley, M. L. (2014). What should school social workers know about children exposed to adult intimate partner violence? Children \& Schools, 36(4), 195-198. https://doi.org/ $10.1093 / \mathrm{cs} / \mathrm{cdu} 023$

Charmaz, K. (2014). Constructing grounded theory. Sage.

Charter, Ottawa. (1986). Ottawa Charter for health promotion. In First international conference on health promotion, 17-21

Convention on the Rights of the Child. (1989). Convention on the Rights of the Child. (20-11-1989 nr 1 Multilateral). Retrieved March 2020 from https://www.ohchr.org/en/professionalint erest/pages/crc.aspx

Eidheim, S. (2007). Å leve på sperret adresse [To live at a confidential address] (PHS Forskning Rapport 1). Oslo: Politihøgskolen. Retrieved April 2020 from https://phs.brage.unit.no/phs-xmlui/ bitstream/handle/11250/175046/Å20leve\%20på\%20sperret\% 20adresse\%20ink1\%20omslag_.pdf?sequence $=1 \&$ isAllowed $=y$

Eriksson, M., Bruno, L., \& Näsman, E. (2013). Domestic Violence, Family Law and School: Children's Right to Participation, Protection and Provision. Palgrave Macmillan Publishers Limited.

Eriksson, M., \& Lindström, B. (2007). Antonovsky's sense of coherence scale and its relation with quality of life: a systematic review. Journal of Epidemiology \& Community Health, 61(11), 938-944. https://doi.org/10.1136/jech.2006.056028

European Court of Human Rights. (1998). Case of A.V. The United Kingdom. Application no. 100/1997/884/1096. Retrieved March 2020 from https://hudoc.echr.coe.int/engitemid:001-58232

Fattore, T., Mason, J., \& Watson, E. (2009). When children are asked about their well-being: Towards a framework for guiding policy. Child Indicators Research, 2(1), 57-77. https://doi.org/10.1007/ s12187-008-9025-3

Folkeregisterloven. (2016). Lov om folkeregistrering [The Population Registry Law]. (LOV-2016-12-09-88). Retrieved March 2020 from https://lovdata.no/pro/\#document/NL/lov/2016-12-09-88? searchResultContext $=1408 \&$ rowNumber $=1 \&$ totalHits $=441$

Frederick, J., \& Goddard, C. (2010). 'School was just a nightmare': childhood abuse and neglect and school experiences. Child \& Family Social Work, 15(1), 22-30. https://doi.org/10.1111/j.13652206.2009.00634.x

Fry, D., Fang, X., Elliott, S., Casey, T., Zheng, X., Li, J., \& McCluskey, G. (2018). The relationships between violence in childhood and educational outcomes: a global systematic review and meta-analysis. Child Abuse \& Neglect, 75, 6-28. https://doi.org/10.1016/j. chiabu.2017.06.021

Grunnloven. (1814). Kongeriket Noregs grunnlov [The Norwegian Constitution]. (LOV-1814-05-17). Retrieved January 2020 from https:// lovdata.no/dokument/NL/lov/1814-05-17-nn\#KAPITTEL_1

Hogan, F., \& O'Reilly, M. (2007). Listening with children: research, policy and practice. In Vision into Practice: Proceedings CECDE International Conference 2007. http://repository.wit.ie/id/eprint/545

Koutselini, M., \& Valanidou, F. (2014). Children living with violence against their mothers: the side effects on their behavior, self-image and school performance. Pedagogy, Culture \& Society, 22(2), 213-231. https://doi.org/10.1080/14681366.2013.815259

Kropp, P. R., \& Gibas, A. (2010). The spousal assault risk assessment guide (SARA). Handbook of violence risk assessment, 227-250

Mayall, B. (2002). Towards a sociology for childhood: thinking from children's lives. Open University Press.

Menneskerettighetsloven [The Human Rights Act]. (1999). Lov om styrking av menneskerettighetenes stilling i norsk rett [Act on strengthening the position of human rights in Norwegian law]. (LOV-1999-05-21-30). Retrieved January 2020 from https:// lovdata.no/pro/\#document/NL/lov/1999-05-21-30

Mullender, A., Hague, G., Imam, U. F., Kelly, L., Malos, E., \& Regan, L. (2002). Children's perspectives on domestic violence. Sage.
Nikupeteri, A., Tervonen, H., \& Laitinen, M. (2015). Eroded, Lost or Reconstructed? Security in Finnish Children's Experiences of Post-Separation Stalking. Child Abuse Review, 24(4), 285-296. https://doi.org/10.1002/car.2411

Nordtveit, B. H. (2016). Schools as protection?: Reinventing education in contexts of adversity. Springer.

Norges Høyesterett [The Norwegian Supreme Court]. (2013). Rt2013-588. Retrieved January 2020from:https://lovdata.no/pro/\# document/HRSIV/avgjorelse/hr-2013-881-a?searchResultCon text $=3980$ \&rowNumber $=1 \&$ totalHits $=50$

Odland, A. M. (2018). Kripos bekymret for sikkerheten til 300 barn [Kripos worried about the safety of 300 children]. Retrieved January 2020 from:https://fontene.no/nyheter/kripos-er-bekymret-forsikkerheten-til-300-barn-6.339.531762.3b71c24342

Opplæringslova [The Norwegian Education Act]. (1998). Lov om grunnskolen og den vidaregåande opplaringa [Law on primary and secondary education]. (LOV-1998-07-17-61). Retrieved January 2020 from https://lovdata.no/pro/\#document/NL/lov/1998-07-1761 ? searchResultContext $=1382 \&$ rowNumber $=1 \&$ totalHits $=1317$

Ot.prp.nr. 25 [proposition to the parliament]. (2008-2009). Om lov om endringer $i$ straffeloven og straffeprosessloven (kontaktforbud med elektronisk kontroll, endring av saks- behandlingsreglene for besøksforbud mv.)[About the Act on amendments to the Criminal Code and the Criminal Procedure Act (restraining order with electronic control, change in the processing rules for restraining orders, etc.)]. Retrieved April 2020 from https://www.regjeringen. no/contentassets/bfcbbae42f7a44e8b234cf77e08b6e4d/no/pdfs/ otp200820090025000dddpdfs.pdf

Politidirektoratet [Police Directorate]. (2014). Risikoverktøyet SARA:SV - Det forebyggende sporet i partnervoldsaker [Risk Assessment Tool SARA: SV - The preventive track in partner violence cases]. Politidirektoratet [Police Directory]

Pomeroy, E. C., \& Garcia, R. B. (2011). Theories of grief and loss: An overview. In E. C. Pomeroy \& R. B. Garcia (Eds.), Children and loss: A practical handbook for professionals, (First edition, 1-16).University press.

Riksadvokaten [The Director of Public Prosecutions]. (2019). Kontaktforbud med elektronisk kontroll [Restraining order with electronic control]. Retrived March 2020 from: https://www.riksadvokaten. no/wp-content/uploads/2019/05/Rundskriv-2-2019-kontaktfor bud-ved-el-kontroll.pdf

Schelbe, L., Chanmugam, A., \& Letendre, J. (2015). Youth participation in qualitative research: Challenges and possibilities. Qualitative Social Work, 14(4), 504-521. https://doi.org/10.1177/2F147 3325014556792

Selvik, S., \& Øverlien, C. (2014). Children with multiple stays at Nordic refuges for abused women: conclusions, challenges, and causes for concern. Nordic Social Work Research, 5(2), 98-112. https://doi.org/10.1080/2156857X.2014.982158

Stanley, N. (2011). Children experiencing domestic violence: a research review. Research in practice.

Straffeprosessloven [The Norwegian Criminal Procedure Act]. (1981). Lov om rettergangsmåten $i$ straffesaker [Law on the procedure in criminal cases]. (LOV-1981-05-22-25). Retrieved March 2020 from https://lovdata.no/pro/\#document/NL/lov/1981-05-22-25? searchResultContext $=1882 \&$ rowNumber $=1 \&$ totalHits $=62936$

Thjømøe, C. M. B. (2017). Retten til utdanning og et liv uten vold. En analyse av rettssikkerheten til" Kode 6 og 7"-barna veiet opp mot rettssikkerheten til voldsutøver [The right to education and a life without violence: An analysis of the security under the law for children living at Code 6 and 7 addresses versus the security under the law for the abuser] (Master's thesis). University of Oslo

Øverlien, C., Jacobsen, M., \& Evang, A. (2009). Barns erfaringer fra livet på krisesenter. En landsomfattende studie om flukten, oppholdet og forestillinger om fremtiden [Children's Experience of 
Life at a Shelter For Battered Women. A Nationwide Study on the Escape, the Stay and Hopes of the Future] (Rapport 2). NKVTS

$\emptyset$ verlien, C. (2010). Children exposed to domestic violence: Conclusions from the literature and challenges ahead. Journal of social work, 10(1), 80-97. https://doi.org/10.1177/2F1468017309350663

$\emptyset$ verlien, C. (2015). Ungdom, vold og overgrep: skolen som forebygger og hjelper [Youth, violence and abuse-school as a preventer and helper]. Universitetsforlaget. $\emptyset$ verlien, C. (2012). Narrating the good life-children in shelters for abused women talk about the future. Qualitative Social Work, 11(5), 470-485. https://doi.org/10.1177/2F1473325011401469

Publisher's Note Springer Nature remains neutral with regard to jurisdictional claims in published maps and institutional affiliations. 